\title{
O medo en abîme: o fantástico à luz do realismo no conto "Sem Olhos" de Machado de Assis
}

\author{
Fear in abîme: the Fantastic in the Light of Realism \\ in Machado de Assis's Short Story "Sem Olhos"
}

FÁBı WAKI [fabwaki@gmail.com]

Universidade de Coimbra, Portugal

\section{RESUMO}

Este artigo examina o conto "Sem Olhos" (1876-77) de Machado de Assis a fim de discutir como nele o autor explora uma estrutura narrativa recorrente nos contos de horror do século XIX europeu para discretamente engendrar uma crítica às relações sociais pequeno-aristocráticas e pequeno-burguesas que são o objeto primário da sua estética realista. Sob um viés impressionista que toma o inquietante freudiano como parâmetro afetivo e estético, mas sem jamais se reduzir a ele, esta discussão busca enfim mostrar como o autor revisa um princípio de credibilidade comum nesses contos para criar uma espécie de "medo en abîme": o relato sombrio do protagonista do conto estrutura um medo diante do sobrenatural, mas, ao invés de terminar como um fim em si mesmo, esse medo acaba por suscitar nos demais personagens um segundo medo, um medo natural, relativo às violências potenciais que coordenam as suas vidas em sociedade.

\section{Palavras-Chave}

Literatura brasileira; literatura fantástica; literatura de horror; século XIX; inquietante

\section{Abstract}

This article examines Machado de Assis's short story "Sem Olhos" (1876-77) to discuss how he explores a narrative structure frequently found in horror narratives of the European 19th century as mediation for a criticism of the social relations that characterize the lower aristocracies and bourgeoisies typically represented in his realist aesthetics. From an impressionistic perspective that takes the Freudian uncanny as an affective and aesthetic parameter - without, however, being restricted to it -, this discussion seeks to show how the writer revises a credibility principle common to many of these stories to create some sort of "fear en abîme": the main character's narrative structures a fear of the supernatural, but, instead of being an end in itself, this fear incites in the other characters a second fear, a natural fear, related to the potential acts of violence that coordinate their lives in society.

\section{KEYWORDS}

Brazilian literature; fantastic literature; horror literature; $19^{\text {th }}$ century; uncanny 


\section{Considerações iniciais}

Algo curioso a se notar na literatura brasileira oitocentista é o fato de que, ao contrário de literaturas como a norte-americana e a europeia, ela não conheceu realmente uma vertente fantástica, quanto menos uma vertente de horror fantástico. Quando remetemos a isso, os títulos e nomes mais comuns são Noite na Taverna (1855) de Álvares de Azevedo (1831-52), "A Dança dos Ossos" (1871) de Bernardo Guimarães (1825-84), "Noivados Trágicos” (1898) de Medeiros e Albuquerque (1867-1934) e, já no início do século XX, “Os Porcos” (1903) de Júlia Lopes de Almeida (1862-1934) e "Dentro da Noite” (1910) de João do Rio (1881-1921). Machado de Assis (1839-1908), por sua vez, o maior expoente da literatura oitocentista no Brasil, escreveu cerca de 15 contos que de alguma forma tocam no gênero fantástico-sem nem sempre, claro, tocarem no gênero do horror; são alguns deles: “O País das Quimeras” (1862), “O Anjo das Donzelas” (1864), "Um Sonho e Outro Sonho" (1892), “O Imortal” (1862), “O Anjo Rafael” (1869), "O Capitão Mendonça” (1870), “A Vida Eterna” (1870), "Mariana” (1871), "Decadência de Dois Grandes Homens” (1873), “A Chinela Turca” (1875), “Os Óculos de Pedro Antão” (1874), “Um Esqueleto” (1875) "Sem Olhos" (1876), "A Mulher Pálida" (1881) e "A Segunda Vida” (1884)․․ Cada um desses contos tem as suas próprias peculiaridades e tentativas de releitura das fórmulas sobrenaturais, mas um deles, a narrativa "Sem Olhos", me parece um caso particularmente notável da consciência que Machado de Assis tinha não apenas da forma que caracterizava o gênero de horror fantástico que predominava na Europa do seu tempo - que já tinha como alguns dos maiores nomes o alemão E.T.A. Hoffmann (1776-1822) e o francês Théophile Gautier (1811-72), dois escritores bastante caros a Machado de Assis -, mas também das capacidades de revolução formal intrínsecas ao gênero realista que vigorava no Brasil e do qual ele próprio era o maior representante.

Neste artigo, então, examinarei o conto "Sem Olhos" a fim de discutir como nele Machado de Assis explora uma estrutura narrativa recorrente nos contos de horror do século XIX para discretamente engendrar uma crítica às relações sociais pequeno-aristocráticas e pequeno-burguesas que são o objeto primário da sua estética realista. Sob um viés impressionista que toma o inquietante [unheimlich] freudiano como parâmetro estético e afetivo, mas sem jamais me reduzir a ele, buscarei enfim mostrar como o autor revisa um princípio de credibilidade comum nesses contos para criar uma espécie de "medo en abîme": o relato sombrio do Desembargador Cruz, protagonista do conto, estrutura um medo e um prazer estético diante do sobrenatural, mas, ao invés de terminar como um fim em si mesmo, esse medo acaba por suscitar em Maria do Céu e no Bacharel Antunes, os principais coadjuvantes, um segundo medo, um medo natural e racional, relativo às violências potenciais que coordenam suas vidas em sociedade.

\section{Os novos círculos íntimos}

Na coletânea intitulada The Oxford Book of Victorian Ghost Stories, publicada pela Oxford University Press em 2003, encontramos quatro narrativas sobrenaturais que se iniciam das seguintes maneiras:

1 Tomo como referência a antologia Contos Fantásticos de Machado de Assis, editado por Raymundo Magalhães Jr. em 1973. (Cf. Magalhães 1973) 
Não me vale a pena contar, esta minha história - ao menos, não me vale a pena escrevê-la. Contada, de fato, como às vezes fui convidado a contá-la, a um círculo de rostos inteligentes e ansiosos, iluminados por uma boa lareira após o jantar em uma noite de inverno, com o vento frio correndo como um lamento do lado de fora, e todos acomodados e aconchegados do lado de dentro, ela se sucedeu - eu o digo, embora não devesse - sempre muito bem. Caneta, tinta e papel são veículos sem vida para o maravilhoso, e o 'leitor' é decididamente uma criatura mais crítica do que o 'ouvinte. Se, no entanto, puderes induzir a teus amigos a que leias para eles ao cair da noite, quando a conversa à lareira já tiver percorrido excitantes contos de horrores sem forma; enfim, se puderes garantir as mollia tempora fandi [ocasiões favoráveis para falar], eu continuarei com meu trabalho, e, devo dizer, também com um coração melhor. Bem, então, essas condições pressupostas, não irei gastar mais palavras, e dir-te-ei simplesmente como tudo aconteceu. (Le Fanu 2003: 19; tradução minha)

"E como interpretas isto?"

"Não interpreto de modo algum. Não finjo entendê-lo."

"Achas, então, que foi mesmo sobrenatural?"

"Sabemos tão pouco o que a Natureza compreende - quais são seus poderes e limites - que mal podemos discutir qualquer coisa que aconteça além ou acima dela.”

"E tens certeza de que isto aconteceu?"

"Muita; com relação a isto não tenho qualquer dúvida."

Essas sentenças se passaram entre dois cavalheiros no escritório de uma casa de campo, onde uma pequena família se reunia após o jantar; e, como consequência de um súbito silenciamento nas conversas, eles foram claramente ouvidos por quase todos os presentes. A curiosidade foi excitada, e perguntas foram ansiosamente feitas com relação à natureza ou sobre-natureza do evento em questão. "Uma história de fantasma!", gritou alguém, “Oh! Que ótimo! Nós devemos e iremos ouvi-la." "Oh, por favor, não.", disse outro; "Assim não irei dormir à noite toda - e, mesmo assim, morro de curiosidade." (Millington 2003: 190; tradução minha)

"Vamos contar histórias de fantasmas, então.", disse Gladys.

"Não estás cansada delas? Não se ouve mais nada hoje em dia. E elas são todas 'autênticas', realmente afiançadas, mas nunca se vê a pessoa que viu ou ouviu ou sentiu o fantasma. É sempre a irmã ou primo de alguém, ou um amigo de um amigo.", protestou Senhorita Snowdon, outra das convidadas em Quarries. (Molesworth 2003: 319; tradução minha)

Monsignor Maxwell anunciou no dia seguinte durante o jantar que já tinha organizado o entretenimento para aquela noite. Um padre, com quem tinha feito amizade no Palatine, estava de partida para a Inglaterra na manhã seguinte; e, portanto, era a nossa única chance de ouvir a sua história. (Benson 2003: 459; tradução minha)

Já em um discurso mais extenso, o escritor russo Aleksei Tolstói (1883-1945) nos oferece uma narrativa de horror que se abre da seguinte forma: 
O ano de 1815 reuniu em Viena o que havia de mais distinto em matéria de erudições europeias, espíritos de sociedade brilhantes e grandes talentos diplomáticos. Entretanto, o Congresso fechara. Os emigrados monarquistas se preparavam para voltar definitivamente a seus castelos, os soldados russos para rever suas casas abandonadas, e alguns poloneses descontentes para levar a Cracóvia seu amor pela liberdade e abrigá-lo sob a tripla e duvidosa independência que lhes havia sido concedida pelos príncipes de Metternich e de Hardenberg e pelo conde de Nesselrode.

$[\ldots]$

Nossas manhãs eram dedicadas aos passeios, jantávamos todos juntos, ora no castelo, ora nos arredores, e à noite, sentados perto de um bom fogo de lareira, divertíamo-nos conversando e contando histórias. Era terminantemente proibido falar de política. Todo mundo estava farto do assunto, e nossos relatos eram emprestados ora das lendas dos nossos países, ora das nossas próprias lembranças.

Uma noite, uma vez que cada um contara alguma coisa e que nossos espíritos se encontravam naquele estado de tensão que a obscuridade e o silêncio, de ordinário, só fazem aumentar, o Marquês de Urfé, velho emigrado de quem todos nós gostávamos por causa de sua alegria tão juvenil e pela maneira picante como falava das suas velhas aventuras, aproveitou um momento de silêncio e tomou a palavra:

"Essas suas histórias," nos disse ele, "são deveras espantosas, mas falta-lhes um ponto essencial que é a autenticidade. Que eu saiba, nenhum dos senhores testemunhou com os próprios olhos essas narrativas maravilhosas nem pode jurar por elas, como cavalheiros que são." (Tolstói 2005: 26-27)

Como vemos, todas essas apresentações se valem de estruturas narrativas semelhantes para introduzir seus eventos sobrenaturais: em todas temos a sugestão de que, em espaços em geral fechados, convenientemente protegidos do frio e da escuridão da noite, não raro com a ajuda do calor de uma lareira, círculos sociais se organizam para ouvir algum dos presentes relatar em primeira ou segunda mão alguma espécie de evento cuja natureza e veracidade escapam à compreensão humana.

Em termos históricos, é provável que essas confraternizações não fossem mesmo raras: por um lado, a industrialização na Europa - em particular na Inglaterra, como epicentro da Revolução Industrial - levou ao êxodo das zonas rurais e à formação de uma nova classe média urbana, que passou a ter nos círculos sociais privados uma nova forma de convivência; por outro lado, esse mesmo processo de industrialização levou a uma configuração das grandes cidades como um espaço de violência e sordidez sociais, o que provavelmente enfatizou os ambientes interiores como espaços para retiro e comunhão cultural. (cf. Hogle 2002: 5; Watt 2000: 62; Robbins apud Cochrane 2013) Já em termos estéticos, um dos efeitos imediatos dessa composição cênica é estruturar um Stimmung sombrio que potencializa a natureza lúgubre dos relatos: a escuridão, o frio e o silêncio noturnos que enclausuram a todos em um ambiente cujas salas e esquinas se tingem por sombras entrecortadas pela luz bruxuleante de uma lareira, o murmúrio da chuva contra as janelas e o uivo do vento, o ribombar de trovões e o ranger das escadas e assoalhos de madeira, o vazio surdo e mudo que se estende pelo lado de fora ou os graves rumores de vozes que escoam pelas ruas sujas e mal iluminadas - todos esses fatores, todas essas intermitências entre luz e cerração, presença e ausência, ruído e mudez, contribuem para a formação de uma ambiência funesta quase palpável que recobre a todos com o véu dos seus próprios receios. Mas isso não é tudo: se, 
por um lado, essa composição permite a estruturação de um Stimmung lúgubre que potencializa a estética apavorante sobre a qual os relatos em geral se estruturam, por outro, o ambiente doméstico das confraternizações sociais, para além de permitir o estreitamento de novos laços como os matrimoniais, eróticos, profissionais ou relativos a posições de classe, também permite, em particular nas narrativas em questão, a formação de uma arena dialógica na qual a razão e a desrazão se engalfinham em uma eterna insolubilidade - uma insolubilidade que, por fim, gera em todo o contexto narrativo um perturbador efeito de verossimilhança.

Esse cenário dialógico, entrecortado por discursos de razão e desrazão, seguramente não é acidental, e, ao mesmo tempo em que talvez seja legítimo supor que esses embates entre o lógico e o ilógico fossem corriqueiros em tais círculos domésticos na Europa oitocentista, parece bastante claro que, em termos estéticos, a súbita impotência da razão diante da desrazão é um dos motores para o desamparo que sentimos ao nos depararmos com os eventos sobrenaturais sustentados nessas narrativas. Em outras palavras, esse artifício narrativo em "moldura" - na qual um relato sobrenatural se configura dentro e diante de um círculo de personagens ouvintes, uns mais racionais e céticos do que outros - promove, em termos estéticos, uma potência de verdade pautada nas angústias, ansiedades e medos que esses personagens sentem, sentimentos que, por sua vez, refletem as sensações de apreensão dos leitores e, ao mesmo tempo, induzem-nos a elas.

Talvez não por acaso, uma das primeiras conclusões às quais Sigmund Freud (1856-1939) chega no seu ensaio O inquietante [Das Unheimliche] (1919; 2010), após uma breve retrospectiva etimológica do adjetivo heimlich, é a de que em diversos pontos do seu uso popular o sentido desse adjetivo se confunde com ou desliza para o sentido de unheimlich, o adjetivo que qualifica o seu oposto. Em outros termos, Freud, ao mapear o emprego do adjetivo heimlich na língua alemã - um adjetivo que literalmente remete a algo como doméstico, familiar ou autóctone -, constata que com frequência o seu sentido degenera para ou é substituído pelo sentido do seu contrário un-heimlich - um adjetivo que logicamente remete então a algo como alheio, estranho ou intruso. É válido enfatizar que nesse jogo semântico o adjetivo original heimlich remete ao racional, lógico, natural e compreensível, enquanto o adjetivo derivado unheimlich remete ao irracional, ilógico, sobrenatural (ou antinatural) e incompreensível.

Assim, retornando à estética das narrativas em apreço, o círculo dialógico que se estrutura nesses ambientes domésticos é fundamental em termos discursivos porque ele garante essa oscilação entre o real e o absurdo, entre o conhecido e o desconhecido, entre o bem-vindo e o intruso; em outras palavras, o aparato psicológico coletivo que se estrutura sobre essa insolubilidade entre razão e desrazão, sobretudo quando potencializado por um Stimmung sombrio que aprofunda em termos afetivos a angústia diante dessa insolubilidade, garante à narrativa um amparo à sua própria necessidade por uma tensão pautada na impossibilidade de resposta, ou na mútua exclusão de respostas racionais e irracionais.

No ensaio de Freud, lemos:

A situação é outra quando o escritor, aparentemente, move-se no âmbito da realidade comum. Então ele também aceita as condições todas que valem para a gênese da sensação inquietante nas vivências reais, e tudo o que produz efeitos inquietantes na vida também os produz na obra literária. Mas nesse caso o escritor pode exacerbar e multiplicar o inquietante para muito além do que é possível nas vivências, ao fazer sobrevir acontecimentos que jamais - ou muito raramente - 
encontramos na realidade. Ele como que denuncia a superstição que ainda abrigamos e acreditávamos superada, ele nos engana, ao prometer-nos a realidade comum e depois ultrapassá-la. Nós reagimos a suas ficções tal como reagiríamos a nossas próprias vivências; ao notarmos o engano, é tarde demais, o autor atingiu seu propósito, mas afirmo que não alcançou pleno êxito. Fica-nos um sentimento de insatisfação, uma espécie de desgosto pelo malogro tentado [...] (Freud 2010: 373)

Algo curioso a se notar a respeito desse ensaio, sobretudo em comparação com os excertos apresentados, que buscam arquitetar uma ambiência lúgubre propícia à discussão de algo por si só aflitivo mas autotelicamente inconclusivo, é o fato de que nele o adjetivo unheimlich, por vezes substantivado como das Unheimliche, é tratado como duas categorias distintas - duas categorias em princípio psicanalíticas, mas expansíveis ao domínio da arte: primeiro, Freud se refere ao inquietante como uma "estética" [Ästhetik] (329), enquanto mais adiante no ensaio ele se refere ao inquietante como um "afeto" [Affekt] (360). Essa diferença de categorias é valiosa para nós porque, embora a ideia de "estética" seja inalienável e seja quase mesmo um pleonasmo da ideia de "afeto", no âmbito da discussão de Freud, que é a mesma em que esta discussão se enquadra, uma "estética" está mais propriamente atrelada à ordem da materialidade, enquanto um "afeto" é por excelência uma categoria atrelada à ordem da imaterialidade - à ordem extralinguística ou antelinguística das intensidades e das mediações, para ser mais exato. Enfatizo aqui essa distinção porque, como veremos a seguir no conto "Sem Olhos", Machado de Assis se dedica detalhadamente à construção de uma estética inquietante, centrada na figura grotesca de Damasceno Rodrigues, mas, ao final, o que podemos considerar justamente como o elemento de originalidade na narrativa, o prazer estético pelo inquietante no relato se traduz nas psiques e nos ânimos de Maria do Céu e do Bacharel Antunes não tanto como um medo sedutor pelo desconhecido [unheimlich], a espécie de medo que gravita a figura de Damasceno e permeia todo o relato do Desembargador Cruz, mas como um medo restritivo pelo conhecido [heimlich] - em particular, um medo diante da possibilidade de represália por parte de Bento Soares, o marido um tanto quanto detestável de Maria do Céu. Não que a narrativa de Machado de Assis como um todo não nos afete à inquietação, ao prazer estético, por sua natureza sombria, angustiante e até pavorosa, sobretudo diante da nossa dúvida com relação à verdadeira essência do que o Desembargador Cruz testemunhou; mas a questão é que, ao fim, remontando já a uma estética propriamente realista, nós constatamos que Maria do Céu e o Bacharel Antunes são menos afetados pelo caráter sobrenatural do relato de Cruz do que pelo caráter factual das possíveis violências - conjugais ou sociais, físicas ou morais - às quais eles por fim imaginam poder estar sujeitos.

\section{Os velhos círculos íntimos}

Publicado pela primeira vez entre 1876 e 1877 no Jornal das Famílias, o conto Sem Olhos de Machado de Assis se inicia da seguinte maneira ${ }^{2}$ :

2 Utilizo como base o texto original publicado no Jornal das Famílias entre Dezembro de 1876 e Fevereiro de 1877 , mas adapto a ortografia do português da época para a norma atual. 
O chá foi servido na saleta das palestras íntimas às quatro visitas do casal Vasconcelos. Eram estas o Sr. Bento Soares, sua esposa D. Maria do Céu, o bacharel Antunes e o desembargador Cruz. A conversa, antes do chá, versava sobre a última soirée do desembargador; quando o criado entrou, passaram a tratar da morte de um conhecido, depois das almas do outro mundo, de contos de bruxas, finalmente de lobisomem e das abusões dos índios.

- Pela minha parte, disse o Sr. Bento Soares, nunca pude compreender como o espírito humano pôde inventar tanta tolice e crer no invento. Vá que uma ou outra criança dê crédito às suas próprias ilusões; para isso mesmo é que são crianças. Mas, que um homem feito...

- Que tem isso? observou o desembargador apresentando a xícara ao criado para que lhe repetisse o chá; a vida do homem é uma série de infâncias, umas menos graciosas que as outras.

(Machado de Assis 1876: 356; ênfase minha)

Como vemos, à semelhança das narrativas europeias apresentadas na seção anterior, o conto de Machado de Assis se inicia pela configuração de um círculo doméstico e íntimo: um casal da classe média carioca, os Vasconcelos, recebem na sala de visitas outras quatro pessoas - o arrogante Bento Soares e sua doce esposa Maria do Céu, o cético e ousado Bacharel Antunes e o recatado e sincero Desembargador Cruz, que é também o narrador e protagonista da história fantástica que estreita a todos em confraternização. A semelhança dessa introdução às das demais narrativas apresentadas é inegável, mas é preciso também atentar para alguns contrastes: primeiro, com relação ao Stimmung sombrio que, embora prevaleça nas narrativas europeias, é desconstruído na narrativa machadiana; segundo, com relação à objetividade da narração que abre o conto, uma objetividade que busca trivializar justamente a natureza sombria que esperaríamos encontrar em um conto sobrenatural a fim de garantir à história uma lógica e uma estética propriamente realistas, ou ao menos predominantemente realistas.

$\mathrm{O}$ fato de Machado de Assis alocar a sua narrativa sobrenatural em um círculo íntimo condiz, como vimos, com uma estrutura narrativa bastante recorrente nos contos de terror da Europa oitocentista; no entanto, é preciso salientar que a sua narrativa não arquiteta um Stimmung lúgubre, sombrio e denso como o daqueles contos - ao contrário: o Stimmung machadiano nessa narrativa se compõe antes do ethos convivial burguês ou talvez aristocrático-burguês que imperava nos lares cariocas na segunda metade do século XIX. A reunião de um círculo de conhecidos cuja amizade é lubrificada pelo chá e por conversas tête-à-tête a respeito de soirées, toilettes e assuntos de negócios; a invisibilidade do criado que garante que as xícaras de chá jamais fiquem vazias; a afetação passiva das mulheres diante da austeridade autoritária dos homens; o desejo por notícias, fofocas e histórias perturbadoras - todos esses discretos laços sociais acabam por compor para o leitor não um Stimmung sombrio que envolve a todos com seu negro manto de apreensão, mas um Stimmung antes estruturado pela perfumada hipocrisia social legitimada e naturalizada nos ambientes domésticos de casais de classe média como os Vasconcelos.

Se nas narrativas europeias há um predomínio da curiosidade ativa dos envolvidos por histórias sobrenaturais que possam se conjugar à escuridade dos ambientes privados das casas vitorianas, na narrativa machadiana há o predomínio de um ceticismo - sobretudo do lado masculino - cujo principal interesse nas histórias sobrenaturais é tê-las como objetos de escárnio e cinismo, comportamento que enfim condiz com a ambiência sórdida típica do grupo de 
filisteus ali reunidos ${ }^{3}$. Não que não existam ouvintes realmente interessados no prazer estético que a natureza inquietante do sobrenatural suscita - o casal Vasconcelos está claramente envolvido pelo fantástico que poderá ser explorado no relato do Desembargador Cruz -, mas o ceticismo e a arrogância de Bento Soares, Maria do Céu e do Bacharel Antunes dão antes o tom cínico que irá envolver o depoimento de Cruz. Com efeito, os Stimmungen lúgubres típicos das narrativas como as que vimos no início deste estudo são reconhecidos por Machado de Assis, mas eles também são logo desconstruídos-desconstrução ativada sobretudo por meio de uma narração objetiva e trivializante, uma narração que é quase uma listagem de elementos a serem considerados e excluídos: "A conversa, antes do chá, versava sobre a última soirée do desembargador; quando o criado entrou, passaram a tratar da morte de um conhecido, depois das almas do outro mundo, de contos de bruxas, finalmente de lobisomem e das abusões dos índios." (Machado de Assis 1876: 356; ênfase minha) É verdade que, tal como nas narrativas europeias, a narrativa machadiana se vale do conflito entre heimlich e unheimlich para predispor os personagens e o leitor à sobrenaturalidade dos eventos que irão se seguir; mas também é importante notar que, em contraste àquelas narrativas, a narrativa machadiana logo de início contextualiza o sobrenatural em um ambiente que no fim é estranho a ele, um ambiente talvez por demais racional, traiçoeiro e resistente - algo, como veremos, propício à estética realista que, embora desestabilizada justamente por meio da ênfase no fantástico, é rigorosamente o gênero no qual o conto afinal se enquadra.

Logo de início, dando sequência a uma lógica estética e a uma crítica moral que irão atravessar grande parte da obra machadiana, o conto nos sugere o seguinte sobre as psicologias e comportamentos de Maria do Céu e do Bacharel Antunes:

- Queres mais chá, Maria? perguntou a dona da casa à esposa de Bento Soares, que acabava de beber a última gota do seu.

- Aceito.

O bacharel Antunes apressou-se a receber a xícara de D. Maria do Céu, com uma cortesia e graça, que the rendeu o mais doce dos sorrisos.

- Eu acompanho o desembargador, disse Bento Soares.

Enquanto o bacharel Antunes ampliava ao marido de Maria do Céu o obséquio que acabava de prestar a esta, com a mesma solicitude, mas sem receber o mesmo nem outro sorriso, e passava ao criado a xícara vazia, Bento Soares prosseguia em suas ideias acerca das abusões humanas.

[...]

A conversa, porém, bifurcou-se; enquanto o desembargador referia a Bento Soares e ao dono da casa algumas notícias relativas a crenças populares antigas e modernas, as duas senhoras conversavam com o bacharel, sobre um ponto de toilette... Maria do Céu era uma mulher bela, ainda que baixinha, ou talvez por isso mesmo, porquanto as feições eram consoantes à estatura: tinha uns olhos miúdos e redondos, uma boquinha que o bacharel comparava a um botão de rosa, e um nariz que o poeta bíblico só por hipérbole poderia comparar à torre de Galaad. A mão, que essa, sim, era um lírio dos vales - lilium convalium -, parecia arrancada a alguma estátua, não de Vênus, mas de seu filho; e eu peço perdão desta mistura de coisas sagradas com profanas, a que sou obrigado pela natureza mesma de Maria do Céu. Quieta, podiam pô-la num altar; mas, se movia os olhos, era pouco menos 
que um demônio. Tinha um jeito peculiar de usar deles que enfeitiçou alguns anos antes a gravidade de Bento Soares, fenômeno que o bacharel Antunes achava o mais natural do mundo. Vestia nessa noite um vestido cor de pérola, objeto da conversa entre o bacharel e as duas senhoras. Antunes, sem contestar que a cor de pérola ia perfeitamente à esposa de Bento Soares, opinava que era geral acontecer o mesmo às demais cores; donde se pode razoavelmente inferir que em seu parecer a porção mais bela de Maria não era o vestido, mas ela mesma. (Machado de Assis 1876: 357; ênfase minha)

Como em várias das narrativas machadianas, tanto anteriores quanto posteriores à sua publicação no Jornal das Famílias, "Sem Olhos" nos apresenta uma pequena ciranda amorosa - um discreto triângulo amoroso, no caso: valendo-se de táticas bastante circunspectas, como sorrisos prudentes e olhares furtivos, gestos de cordialidade talvez afetados demais e conversas talvez íntimas demais sobre assuntos talvez incomuns demais, Maria do Céu e o Bacharel Antunes, mesmo próximos ao marido dela e em meio a amigos comuns, demonstram um claro interesse erótico um pelo outro. Sob uma perspectiva social ou antropológica, uma importância desse pequeno jogo amoroso está no fato de que o conto foi publicado em um periódico mensal sugestivamente intitulado Jornal das Famílias, um jornal conservador orientado ao público feminino e, o que talvez parecesse uma lógica natural, à defesa da moralidade pública e à pureza dos costumes.

[Avaliando] o contexto original em que Machado de Assis produziu os seus primeiros contos, podemos notar [...] que as condições e critérios impostos pelo periódico em questão podem implicar em transformações e variações que vão desde aspectos aparentemente triviais, como a extensão das histórias, feitas até certo ponto sob medida, até critérios ideológicos, temáticos e de qualidade literária, possibilitando-nos também o conhecimento de importantes informações a respeito do público ao qual Machado se dirigia. (Crestani 2006: 147-48; ênfase minha).

No entanto, sob uma perspectiva estética, esse triângulo é importante por outros dois motivos, complementares: o primeiro é o fato de que tal tensão erótica - que antepõe Bento Soares, um sujeito arrogante mas em princípio moralmente íntegro, a Maria do Céu e ao Bacharel Antunes, dois jovens aparentemente amáveis mas também aparentemente dispostos à imoralidade - contribui para subverter o Stimmung sombrio que esperaríamos encontrar em uma narrativa de horror sobrenatural, sobretudo se tomarmos como parâmetro as narrativas europeias como as apresentadas acima; o segundo é o fato de que essa tensão, que se nos apresenta em princípio como secundária à tensão sobrenatural que coordena a narrativa, se torna ao fim do conto um claro objeto de crítica social - na verdade, o principal objeto de crítica social em toda a história, o que garante a esse conto um lugar na estética realista machadiana apesar da sua veia sobrenatural. De fato, após a insistência dos ouvintes - divididos, como nas narrativas europeias, entre os céticos e os curiosos, um conflito que justamente incrementa o potencial perturbador do conto -, o Desembargador Cruz se resigna a relatar uma sequência de eventos sinistros de que tomou parte em sua juventude.

Resumo em termos críticos esses eventos, procurando destacar os recursos semânticos e narrativos que Machado de Assis utiliza para construir um Stimmung sombrio, dessa vez intrínseco ao testemunho do então jovem Desembargador Cruz: 
Quando ainda era jovem e recém-formado, Cruz se viu morador da Rua Misericórdia, no Rio de Janeiro, aonde ia para estar próximo de uma namorada. Habitante de uma casa antiga de três andares, Cruz tinha como vizinhos um pajem e, no andar de cima, um certo Damasceno Rodrigues, sujeito de aparência e modos estranhos, "um homem de quarenta anos que parecia ter mais de cinquenta, tão alquebrado e encanecido estava." (Machado de Assis 1876: 359)

Contudo, após superar a impressão inicial de estar diante de alguma estirpe de degenerado social, Cruz se vê não apenas como um amigo de Damasceno, mas como o seu único amigo, como a única pessoa inclusive inclinada a dispor do seu tempo para amparar o velho decrépito no que parecem ser os seus últimos momentos em vida. Essa relação, porém, embora se estabeleça de modo relativamente rápido, não ocorre sem algumas perturbações; ao subir pela primeira vez ao apartamento de Damasceno, Cruz relata o seguinte a respeito do lugar:

O segundo andar era antes um sótão puxado à rua; compunha-se de uma sala, uma alcova e pouco mais. Subi. Achei-o na sala, estirado em uma rede, a olhar para o teto. Tudo ali era tão velho e alquebrado como ele; três cadeiras incompletas, uma cômoda, um aparador, uma mesa, alguns farrapos de um tapete, ligados por meia dúzia de fios, tais eram as alfaias da casa de Damasceno Rodrigues. As janelas, que eram duas, adornavam-se com umas cortinas de chita amarela, rotas a espaços. Sobre a cômoda e a mesa havia alguns objetos disparatados; por exemplo, um busto de Hipócrates ao pé de um bule de louça, três ou quatro bolos, meio pote de rapé, lenços e jornais. No chão também havia jornais e livros espalhados. Era ali o asilo do vizinho misterioso. (Machado de Assis 1877a: 15-16; ênfase minha)

Essa descrição tão detalhada de Cruz a respeito do hábitat de Damasceno não deixa de nos saltar aos olhos, uma vez que há nela um princípio de indefinição: pela conversa inicial entre Cruz e os demais convidados dos Vasconcelos, aprendemos que o seu relato é, enfim, o relato sobre uma aparição estranha - um fantasma, um espírito, uma alucinação - que ele afirma ter se materializado diante dos seus olhos; no entanto, todo o seu relato, sobretudo quando dedicado à aparência e ao comportamento de Damasceno, nos mergulha em uma segunda apreensão, que deixa a sua narrativa tão mais ambígua quanto inquietante: embora saibamos que o relato de Cruz consiste sobretudo nas circunstâncias em que ele testemunhou um fenômeno fantasmagórico, esse relato também toca no tema da loucura, um tema que, embora da ordem da mundaneidade, é sem dúvida um fator de inquietação e ansiogênese, em particular para a psicologia social do século XIX. Assim, um dos motivos estéticos pelos quais Machado de Assis provavelmente investe na loucura de Damasceno, configurada pela sua aparência grotesca, pela ambientação funesta que ele cria ao seu redor e pelo seu comportamento um tanto errático, é o fato de que os distúrbios mentais, sendo por si sós fatores de inquietação pública, acabam por aprofundar ou incrementar a atmosfera perturbadora e os eventos sobrenaturais do relato de Cruz - sem contar, como veremos, o fato de servir como base para mitigar a verdadeira natureza fantástica dos acontecimentos.

De toda forma, embora esse seu relato enfatize a constituição patológica e a configuração espacial que promovem uma estética e um Stimmung sombrios à narrativa como um todo, Cruz logo indica sentir, na verdade, uma empatia por Damasceno, um sentimento que se intensifica após esse lhe confidenciar aquele que é provavelmente o seu maior segredo. 
Já no leito de morte, após ser acometido por um súbito mal-estar, Damasceno entrega a Cruz um maço de documentos antigos, em meio aos quais há a foto de Lucinda, uma jovem cuja beleza singular se firma sobretudo no encanto e no mistério dos seus olhos. A respeito dela, Damasceno explica que era uma jovem por quem se apaixonou muitos anos antes, quando ainda era funcionário em um engenho em Jeremoabo, uma pequena cidade no interior da Bahia. Ela, uma garota bondosa e terna, era casada com um homem terrível, alguém que depositava sobre ela todo o peso do seu ciúme - uma situação de cárcere privado e emocional que não passou despercebido ao também bondoso Damasceno:

Lucinda não me olhava nunca. Era medo, era talvez intimação do marido. Se me falava alguma vez era secamente e por monossílabos. Meu coração deixou-se ir da compaixão ao amor pelo mais natural dos declives, amor silencioso, cauto, sem esperança nem repercussão. Um dia, em que a vi mais triste que de costume, atrevi-me a perguntar-lhe se padecia. Não sei que tom havia em minha voz, o certo é que Lucinda estremeceu, e levantou os olhos para mim. Cruzaram-se com os meus, mas disseram nesse único minuto - que digo? nesse único instante, toda a devastação de nossas almas; corando, ela abaixou os seus, gesto de modéstia, que era a confirmação de seu crime; eu deixei-me estar a contemplá-la silenciosamente. No meio dessa sonolência moral em que nos achávamos, uma voz atroou e nos chamou à realidade da vida. Ao mesmo tempo achou-se defronte de nós a figura do marido. Nunca vi mais terrível expressão em rosto humano! A cólera fazia dele uma Medusa. Lucinda caiu prostrada e sem sentidos. (Machado de Assis 1877b: 45)

Damasceno enfatiza esse evento porque é também a circunstância que o leva a se demitir do engenho e, como ele viria a descobrir depois, que leva o velho marido de Lucinda, em um ato de ciúme e ódio calculados, a lhe arrancar os olhos com um ferro em brasa - uma atitude que o marido chega a justificar com uma espécie de ironia lógica: "Os olhos delinquiram, os olhos pagaram." (Machado de Assis 1877b: 47)

No entanto, não bastasse a sordidez do relato de Damasceno, em larga medida fundada na crueldade do marido e na aparência perturbadora de Lucinda, quando o foco narrativo retorna ao seu quarto no Rio de Janeiro, deparamo-nos com um segundo evento perturbador, mais propriamente da ordem do fantástico. Em um novo surto de alucinações e pânico, Damasceno afirma a Cruz que vê diante de si uma manifestação, uma aparição fantasmagórica: ele afirma que Lucinda, sem olhos e com o rosto ensanguentado, se prostra ao pé da cama, como uma espécie de comensal da morte que veio se ocupar do seu fim e da sua alma. Em princípio, Cruz toma o súbito ataque de pânico como mais uma alucinação de uma mente adoentada e perturbada, mas, ao seguir o pedido do amigo e observar ou olhar para a suposta manifestação ao pé da cama, o que se sucede de fato lhe corrompe o espírito:

— Vai-te! exclamou ele aflito. Vai-te! ainda não!... Olhe!... Olhe! lá está ela! lá está!... O dedo magro e trêmulo apontava alguma coisa no ar, enquanto os olhos, naturalmente fixos, resumiam todo o terror que é possível conter a alma humana. Insensivelmente olhei para o lugar que ele indicava... Olhei; e podem crer que ainda hoje não esqueci o que ali se passou. De pé, junto à parede, vi uma mulher lívida, a mesma do retrato, com os cabelos soltos, e os olhos... Os olhos, esses eram duas cavidades vazias e ensanguentadas. (Machado de Assis 1877b: 47; ênfase minha) 
Diante de tal perturbação, Cruz cai desfalecido; só recobra os sentidos algumas horas depois, já na sua própria cama e cercado de amigos a quem tinha pedido ajuda durante a doença e as alucinações de Damasceno. Com efeito, eles lhe explicam que o velho enfim morrera enquanto estava inconsciente e o seu luto, o seu lamento pelo fim do estranho e breve amigo, acaba por se confundir com o seu período de recuperação das forças e da lucidez. As circunstâncias torpes e sobrenaturais do relato de Cruz - o relato em segunda mão das memórias de Damasceno e em primeira mão das suas próprias memórias e testemunhos - terminam com essa breve tragédia; no entanto, de volta à roda de amigos, ao ser questionado por Vasconcelos a respeito da verdadeira natureza dos eventos, ele observa que há um epílogo à história - um epílogo que, como vemos, embora aprofunde a natureza misteriosa das memórias de Damasceno, acaba por atenuar a verdadeira essência sobrenatural dos eventos:

- Quando referi a aparição a algumas pessoas, ninguém me deu crédito; e os mais polidos atribuíam o caso a um pesadelo. Evitei expor-me à incredulidade e ao ridículo. Mais tarde, já senhor de mim, determinei contar a catástrofe de Damasceno em um jornal que escrevíamos na Academia. Tratando de colher alguma coisa mais acerca do infeliz, vim a saber, com grande surpresa minha, que ele nunca estivera na Bahia, nem saíra do Sul. Já então não era só o interesse literário que me inspirava; era a liquidação de um ponto obscuro e a explicação de um fenômeno. Casara aos vinte e dois anos em Santa Catarina, de onde só saiu aos trinta e três, não podendo, portanto, encontrar-se com o original do retrato, aos vinte e cinco, solteiro, em Jeremoabo; finalmente, a miniatura que me confiara era simplesmente o retrato de uma sobrinha sua, morta solteira. Não havia dúvida: o episódio que ele me referira era uma ilusão como a da lua, uma pura ilusão dos sentidos, uma simples invenção de alienado. (Machado de Assis 1877b: 48-49)

A habilidade narrativa de Machado de Assis, no entanto, nos surpreende mais uma vez: o comentário de Cruz sobre haver um "epílogo" à história de Damasceno acaba por ser uma espécie de metacomentário, um comentário que o narrador, por meio de Cruz, tece a respeito da própria narrativa fantástica que vem narrando; da mesma forma que as memórias de Cruz sobre Damasceno não se encerram com a morte desse, mas com uma sequência de eventos disparatados que tornam todo o teor do seu relato mais enigmático (e que talvez confirmem o fato de que ele era, enfim, apenas alguém não totalmente em controle dos próprios juízos), o conto "Sem Olhos" não se encerra com essa revelação inquietante dos eventos sobrenaturais, como em geral acontece nas narrativas europeias a que nos referimos.

Em uma espécie de retomada realista, a narrativa do conto se conclui da seguinte maneira:

- Sendo assim, como vi eu a mulher sem olhos? Esta foi a pergunta que fiz a mim mesmo. Que a vi, é certo, tão claramente como os estou vendo agora. Os mestres da ciência, os observadores da natureza humana lhe explicarão isso. Como é que Pascal via um abismo ao pé de si? Como é que Bruto viu um dia a sombra de seu mau gênio?

- O seu caso é talvez mais simples que esses todos; o desvario do doente foi contagioso, e fez com que o senhor visse o que ele supunha ver.

- Pois é pena! exclamou o desembargador; a história de Lucinda era melhor que fosse verdadeira. Que outro rival de Otelo há aí como esse marido que queimou com um ferro em brasa os mais belos 


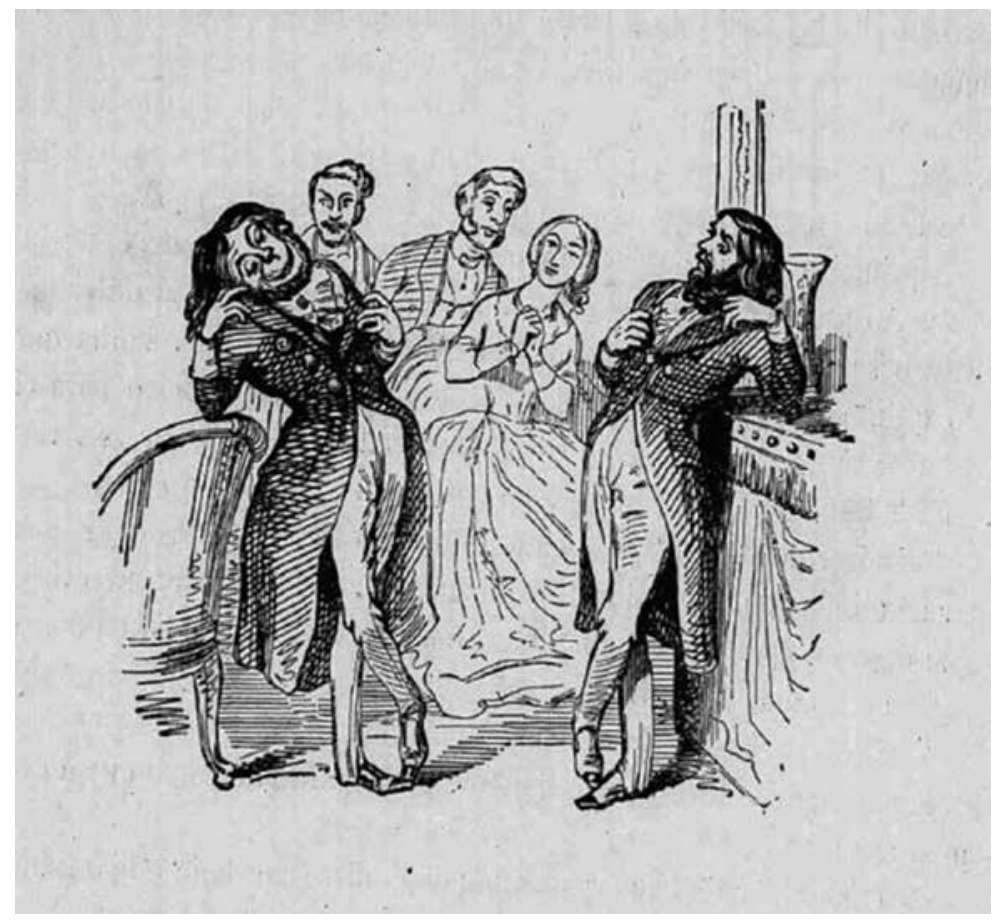

Ilustração ao fim da primeira parte do conto "Sem Olhos", publicada no Jornal das Famílias em Dezembro de 1876.

olhos do mundo, em castigo de haverem fitado outros olhos estranhos? Crê agora em fantasmas, D. Maria do Céu?

Maria do Céu tinha seus olhos baixos. Quando o desembargador lhe dirigiu a palavra, estremeceu, ergueu-se. O bacharel fez o mesmo; mas foi dali a uma janela - talvez tomar ar - talvez refletir a tempo no risco de vir a interpretar algum dia um hebraísmo das Escrituras.

(Machado de Assis 1877b: 49: ênfase minha)

Ou seja, ao invés de se concluir com uma espécie de clímax sombrio ou aterrorizante que enfatize a sua natureza fantástica, a narrativa se encerra com uma análise psicológica desses dois personagens coadjuvantes, uma análise que é uma crítica moral bastante consistente não apenas com a estética realista machadiana, mas também com o viés prescritivo do Jornal das Famílias. Ao serem interpelados pela história de Damasceno - isto é, não só pelo seu teor sobrenatural, que culmina na aparição de um fantasma aos olhos do próprio Cruz, mas sobretudo nas circunstâncias trágicas e sórdidas que levam Lucinda a ter os olhos arrancados com um ferro em brasa -, Maria do Céu e o Bacharel Antunes flagram a si mesmos ponderando sobre as suas próprias intenções e comportamentos. Em outras palavras, se, no início do conto, nós temos um vislumbre das atitudes discretamente licenciosas que unem os interesses eróticos e ilícitos de Maria do Céu aos do Bacharel Antunes, no fim do conto, após a revelação de que Damasceno é o que é em decorrência de uma paixão também ilícita, vemos como o casal carioca reexamina tais atitudes. Não que esse 
exame de consciência seja uma espécie de conscientização moral efetiva - não: esse exame de consciência é antes uma espécie de cálculo de autopreservação, de reação ao medo, de ponderação a respeito do que lhes pode acontecer na prática caso Bento Soares venha a querer reagir contra as suas intenções eróticas.

\section{Considerações finais}

Como vimos, uma das principais características do conto "Sem Olhos", de Machado de Assis, é o fato de que a sua narrativa se aproveita de uma estrutura comum a vários contos sobrenaturais europeus do século XIX para discretamente engendrar uma crítica social mais propriamente consistente com a estética realista que vigorava no Rio de Janeiro da época. Em termos sociais e antropológicos, essa crítica social em muito se explica pelo viés prescritivo e moralizante do Jornal das Famílias, um periódico conservador que tinha como um dos seus principais objetivos prezar pelos bons costumes e pela ordem social cariocas. De todo modo, fato é que Machado de Assis demonstra grande conhecimento pela forma das narrativas sobrenaturais europeias da sua época, a ponto de saber explorá-las em seu próprio benefício. O resultado mais notável desse conhecimento, desse domínio da forma narrativa, está no fato de que o conto, em uma "estrutura por molduras", é bem-sucedido em arquitetar uma estética sombria - fundamentada sobretudo na aparência grotesca e nos comportamentos erráticos de Damasceno, bem como na violência que acaba por acometer a bela Lucinda -, mas é também bem-sucedido em não desestruturar ou suplantar a estética realista que Machado de Assis veio a consagrar.

É possível afirmar que essa estética realista e o teor irônico e moralizante do seu desfecho mitiguem a natureza fantástica que se apresenta de início, na introdução da narrativa; mas também é possível afirmar que, no conto, o afeto do medo acabe por desempenhar um papel mais central do que a estética do medo, estratégia narrativa que se confirma no fato de que Maria do Céu e o Bacharel Antunes reveem completamente os seus comportamentos ilícitos de um para com o outro, o que, por sua vez, confirma a violência potencial como método de organização moral e social. É importante notar que, embora "Sem Olhos" tenha sido publicado em um periódico conservador, o crivo moral dos editores pode não ter sido tão apurado quanto a habilidade narrativa de Machado de Assis: embora o início e o encerramento do conto dialoguem em uma espécie de tentativa de prescrição moral aos leitores da publicação, os mesmos eventos narrados denunciam a hipocrisia social estruturalizada nos laços pequeno-burgueses que vinham se fortalecendo no Rio de Janeiro da época, hipocrisia que inclusive fazia com que o Jornal das Famílias existisse em primeiro lugar. 


\section{Referências bibliográficas}

Benson, R. H. (1992). Father Macclefield's Tale. In M. Cox, \& R. A. Gilbert (Eds.), The Oxford Book of Victorian Ghost Stories (pp. 459-467). Oxford: Oxford University Press.

Cochrane, K. (2013). Ghost Stories: Why the Victorians Were so Spookily good at Them. In The Guardian. <https://www.theguardian.com/books/2013/dec/23/ghost-stories-victorians-spookily-good>

Crestani, J. L. (2006). A Colaboração de Machado de Assis no 'Jornal das Famílias': Subordinações e Subversões. Patrimônio e Memória, 2 (1), 146-175.

Freud, S. (2010). O inquietante. In Freud (1917-1920): "O Homem dos Lobos" e Outros Textos (pp. 329-376). São Paulo: Companhia das Letras.

Hogle, J. E. (2002). Introduction: the Gothic in Western Culture. In The Cambridge Companion to Gothic Fiction (pp. 1-20). Cambridge: Cambridge University Press.

Le Fanu, J. S. (1992). An Account of Some Strange Disturbances in Aungier Street. In M. Cox, \& R. A. Gilbert (Eds.), The Oxford Book of Victorian Ghost Stories (pp. 19-36). Oxford: Oxford University Press.

Machado de Assis, J. M. (1876). Sem Olhos. Jornal das Famílias, 356-360.

. (1877a). Sem Olhos. Jornal das Famílias, 44-49.

. (1877b). Sem Olhos. Jornal das Famílias, 41-49.

Magalhães Jr., R. (1973). Contos Fantásticos de Machado de Assis. Rio de Janeiro: Edições Bloch.

Millington, T. S. (1992). No Living Voice. In M. Cox, \& R. A. Gilbert (Eds.), The Oxford Book of Victorian Ghost Stories (pp. 190-197). Oxford: Oxford University Press.

Molesworth, M. L. (1992). The Story of the Rippling Train. In M. Cox, \& R. A. Gilbert (Eds.), The Oxford Book of Victorian Ghost Stories (pp. 319-327). Oxford: Oxford University Press.

Tolstói, A. (2005). A Família do Vurdalak. In Contos de Horror do Século XIX (pp. 25-50). São Paulo: Companhia das Letras.

Watt, R. J. C. (2000). Hopkins and the Gothic Body. In Victorian Gothic: Literary and Cultural Manifestations in the Nineteenth Century (pp. 60-89). Hampshire: Palgrave. 
